\title{
Performance of wastewater treatment during variable temperature
}

\author{
Hussein Abed Obaid Alisawi ${ }^{1}[$
}

Received: 16 December 2017 / Accepted: 26 February 2020 / Published online: 7 March 2020

(c) The Author(s) 2020

\begin{abstract}
The general aims of the biological treatment of wastewater (BTW) are to convert (i.e., oxidizes) dissolved and particulate decomposable elements into satisfactory end products. Biological process produces huge quantity of biological wastewater sludge composed of water, microorganisms, and organic and inorganic constituents, for example, phosphorus (P) and nitrogen $\left(\mathrm{N}_{2}\right)$ as well as many contaminants such as substantial metals, organic pollutants and pathogen in waste sludge. BTW is affected by various factors, among which temperature is the major one. In coldest and hottest regions, there are enormous challenges, and it is difficult to understand what the optimal treatment of wastewater is, particularly if the temperature is changed from less than $4{ }^{\circ} \mathrm{C}$ and more than $70{ }^{\circ} \mathrm{C}$. This article presents an exhaustive review of previous studies and suggests a direction for future developments. It is expected that this study will make understanding of behavior of the biological treatment during extreme circumstances.
\end{abstract}

Keywords Biological wastewater treatment $\cdot$ Effect of temperature $\cdot$ Operation modeling

$\begin{array}{ll}\text { Abbreviations } \\ \mathrm{C} & \text { Celsius } \\ \mathrm{TSS} & \text { Total suspended solid } \\ \mathrm{CFU} & \text { Colony-forming unit } \\ \mathrm{N}_{2} & \text { Nitrogen } \\ \mathrm{P} & \text { Phosphorus } \\ \mathrm{K}_{2} & \text { Reaeration coefficient } \\ \mathrm{DO} & \text { Dissolved oxygen } \\ \mathrm{H}_{2} \mathrm{~S} & \text { Hydrogen sulfide } \\ \mathrm{BOD} & \text { Biological oxygen demand } \\ \mathrm{BNR} & \text { Biological nutrient removal } \\ \mathrm{CO}_{2} & \text { Carbon dioxide } \\ \mathrm{BTW} & \text { Biological treatment of wastewater }\end{array}$

\section{Introduction}

Sewage is defined as a combination of watery sludge (a) generated by residences, commercial buildings and industrial establishments; (b) admitted to or find its way into ground, surface, and storm water sewers (Stul and McGhee

Hussein Abed Obaid Alisawi

hussein.alkaisy@outlook.com

$1 \quad$ Alkafeel Center for Studies, Researches and Engineering Consultations, Karbala City Centre, Alabass Holy Shrine Organization, Karbala, Iraq
1982; Tchobanoglous et al. 1991). The conformation of domestic sewage is almost less changeable than industrial wastewater. Generally, the organic wastewater composition is evaluated that contained: $50 \%$ of proteins, $40 \%$ of carbohydrates, $10 \%$ of fats and oils, and trace quantities (e.g., $\mu \mathrm{g} / \mathrm{L}$ or less) of significance contaminates, surfactants and developing pollutants. Furthermore, sewage repeatedly holds 105-108 colony-forming unit (CFU)/mL of coliform bacteria, 103-104 CFU/mL fecal streptococci, 101-103 CFU/ $\mathrm{mL}$ protozoan cysts and $101-102 \mathrm{CFU} / \mathrm{mL}$ virus particles (Saliby et al. 2008). Untreated wastewater is considered as the most significant resultant ecological dilapidation and related public health matters in urban area (Obaid et al. 2015). As study into characteristics of sewage had become more inclusive, the mechanisms for examining specific elements and their probable health and environment impacts are becoming universal.

There are many methods for wastewater treatment such as preliminary, primary, advanced primary, secondary, secondary with nutrient removal (biological and chemical), tertiary and advanced. Each of methods has some obstacles (Metcalf and Eddy 2004).

The temperature is considered the most challenging one in wastewater treatment methods, particularly BTW (Obaid et al. 2015). However, the temperature of wastewater is indicated as a quite major parameter that has effect on biological treatment, aquatic life and appropriateness of the water for 
useful uses (Metcalf and Eddy 2004). Basically, increase in the temperature of the wastewater caused a change in the species of fish that exist in the water body, solubility of oxygen in water (decrease in the saturation concentration $C \mathrm{~s}$ ), acceleration of the process of the oxygen adsorption, the activity rate of bacteria and the rate of gases which are transferred to and from water (Viessman et al. 2009; Von Sperling and de Lemos Chernicharo 2005; Von Sperling 2007; Popel 1979) that leads to increase the reaeration coefficient $\left(K_{2}\right)$. Moreover, oxygen is considered less soluble in warm water than in cold water, and dissolved oxygen has been affected by the variation of temperature at the saturation as shown in Table 1. Moreover, the effect of temperature reduces with the increase in the age of sludge (Eckenfelder 1980). Moreover, the inactivation of the pathogenic microorganisms occurs mainly by the increase in temperature during the highest activity phase of the process. Temperature affects reaction rates of most chemical and biological processes. In addition, high temperatures can accelerate odor generation (Von Sperling 2007).

Table 1 The effects of temperature on dissolved oxygen at saturation (Metcalf and Eddy 2003)

\begin{tabular}{ll}
\hline Temperature $\left({ }^{\circ} \mathrm{C}\right)$ & $\begin{array}{l}\text { Concentration of dis- } \\
\text { solved oxygen (DO) } \\
(\mathrm{mg} / \mathrm{L})\end{array}$ \\
\hline 0 & 14.6 \\
5 & 13.1 \\
10 & 11.3 \\
15 & 10.1 \\
20 & 9.1 \\
25 & 8.2 \\
\hline
\end{tabular}

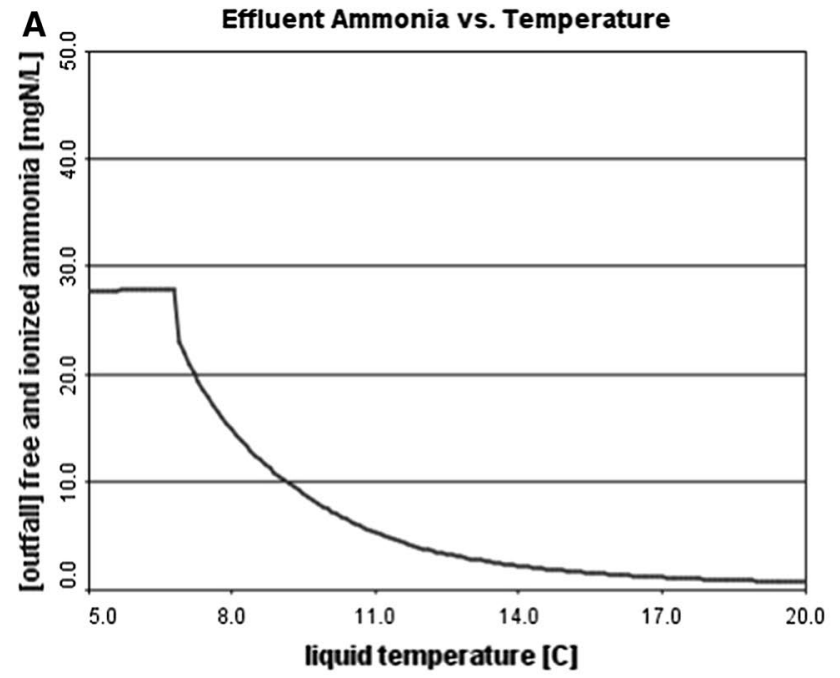

Temperature has a decisive role in many processes of wastewater treatment; normal temperatures decrease land requirements, enhance conversion processes, increase efficiencies of removal and make the utilization of some treatment processes feasible. Besides that, anaerobic reactors may be utilized for diluted wastewater, such as domestic sewage, only in warm climate areas. Moreover, stabilization ponds may be applied in lower-temperature areas, but occupy much larger areas and be subjected to a decrease in performance during winter. Particularly, the free ammonia proportion at $25{ }^{\circ} \mathrm{C}$ relative to the total ammonia is approximately the double compared with $15^{\circ} \mathrm{C}$ (Von Sperling 2007). Moreover, the sensitivity of a nitrifying plant to wastewater temperature is determined while experiencing a sinusoidal influent flow rate by GPS-XTM runs a fiveday dynamic simulation with a sinusoidal influent flow rate. Figure 1a shows automatic steady-state sensitivity analysis of effluent ammonia vs. wastewater temperature, and Fig. 1b illustrates automatic sensitivity analysis of effluent ammonia vs. time (for three different temperatures); there is an increased nitrification occurring at higher influent temperatures. The concentration of effluent ammonia varies with time due to the sinusoidal influent flow rate (Hydromantis 2020).

On the other hand, activated sludge and aerobic biofilm reactors are less dependent on temperature, and additionally, different temperatures interfere with the bacteria's metabolism (Von Sperling 2007). There are four types of microbial communities regarding the supporting temperature in wastewater: First, mesophiles temperature is ranging between 10 and $45^{\circ} \mathrm{C}$ and the optimum degree of temperature is $32.5^{\circ} \mathrm{C}$. Second, thermophilic temperature is ranging from 40 to $75^{\circ} \mathrm{C}$, in which $60{ }^{\circ} \mathrm{C}$ is considered an ideal

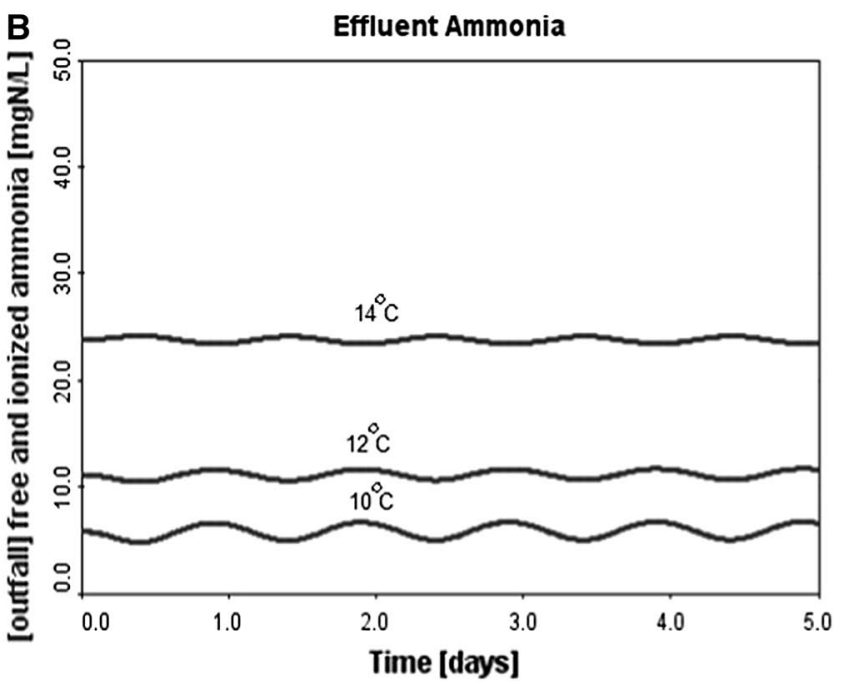

Fig. 1 a Automatic steady-state sensitivity analysis of effluent ammonia versus wastewater temperature and $\mathbf{b}$ automatic sensitivity analysis of effluent ammonia versus time (for three different temperatures) 


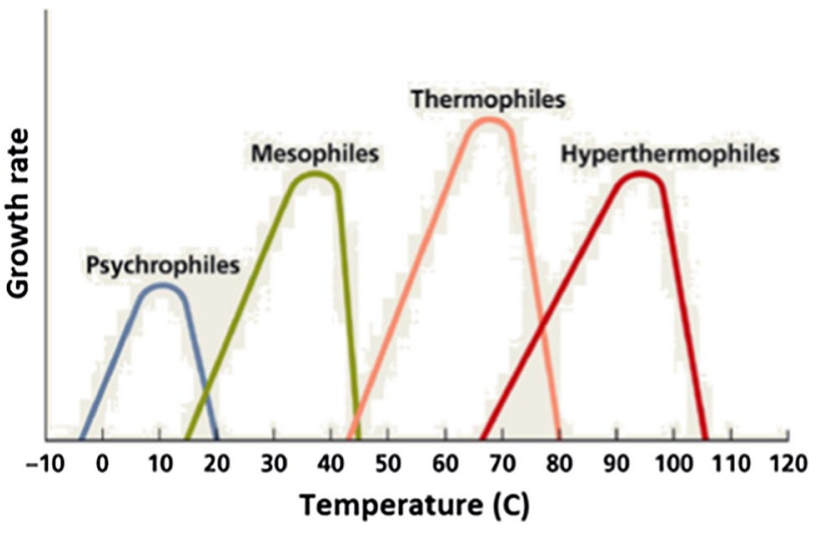

Fig. 2 Four types of microbial communities (mesophiles, thermophiles, psychrophiles and heterotrophiles)

temperature. Third, psychrophiles grow in temperature range between 0 and $20^{\circ} \mathrm{C}$ in which $12.5^{\circ} \mathrm{C}$ represents the optimum temperature. Four, some of heterotrophic microorganisms grow at temperature above $100{ }^{\circ} \mathrm{C}$. These conditions are shown in Fig. 2 (Eckenfelder 1980).

Occasionally, the average annual temperature for wastewater depends on the geographic area; for example, in the USA it changes between 3 and $27^{\circ} \mathrm{C}$ in which $15^{\circ} \mathrm{C}$ is a typical value (Eckenfelder and O'Connor 2013). Nevertheless, Metcalf and Eddy (2004) reported the abnormal highest rate of temperature could foster growth of disagreeable water plants and wastewater pestilence (American Public Health Association 1995). The overall efficiency of the biological treatment process is significantly affected by the temperature dependence of the biological reaction-rate parameters as a function of temperature through the formulation according to van't Hoff-Arrhenius equation which is shown below (Sawyer et al. 1978; Metcalf and Eddy 2003):

$K_{T}=K_{20} \theta^{(T-20)}$

Iwhere $K_{\mathrm{T}}=$ coefficient of reaction rate at temperature $T,{ }^{\circ} \mathrm{C}$, (if the temperature increases $1{ }^{\circ} \mathrm{C}$, then there is an increase in the $K_{\mathrm{T}}$ to $7 \%$ (Yánez Cossio 1993), $K_{20}=$ coefficient of reaction rate at temperature $20{ }^{\circ} \mathrm{C}, \theta=$ coefficient of temperature activity, and $T=$ temperature, ${ }^{\circ} \mathrm{C}$.

Many studies have provided much information related to BTW; unfortunately, they did not focus on the effects of temperature on the biological treatment. Advanced biological technologies introduced for last five decades for estimation of the impacts of temperature on biological treatment of sewage are reviewed briefly, particularly the impacts of temperature on activated sludge process, lagoons and trickling filter. Therefore, the purpose of this review is to determine the impacts of temperature changes that affect the efficiency of BTW in different situations. It provides an overview of the limitations of effects of temperature on units of biological treatment.

\section{Aerobic (oxic) process}

It occurs in the presence of oxygen. The operation pattern of aerobic biological treatment is in mesophilic range, by increasing the temperature up to $31{ }^{\circ} \mathrm{C}$, that leads to increase in the rate of biological reaction in the overall aerobic system as shown in Fig. 3. The figure illustrates the rate of mesophilic microorganism will decrease in the temperature above $39{ }^{\circ} \mathrm{C}$ (Eckenfelder and O'Connor 2013). The degradation in biological floc will increase at temperature over $35.5^{\circ} \mathrm{C}$. At temperature $40{ }^{\circ} \mathrm{C}$, all of cryptosporidium, Entamoeba histolytica and Giardia lamblia will disappear, and they have a scattered flocculation with fiber at $43.3^{\circ} \mathrm{C}$ (Eckenfelder and O'Connor 2013; Batstone et al. 2002).

The process of digestion of aerobic and nitrification will be inactive when a temperature becomes above $50{ }^{\circ} \mathrm{C}$. On the other hand, production of methane by bacteria will stop when the temperature becomes under $15^{\circ} \mathrm{C}$. The temperature acceptance for operation of activated sludge process is around $37.5^{\circ} \mathrm{C}$. It is considered the highest temperature for mesophilic microorganism growth; additionally, the temperature will increase because of oxidation process (Grady et al. 1984). The growth of impurities-resulting thread like microorganisms usually become strewn about when the temperature for an aeration tank above $35{ }^{\circ} \mathrm{C}$ and less than $40{ }^{\circ} \mathrm{C}$ (Jenkins 1992). Furthermore, an aerobic treatment is affected by a kinetic viscosity (v) of wastewater, as shown in Eq. 2 (Sawyer et al. 1978) below:

$v=0.325 * T^{-0.450}$

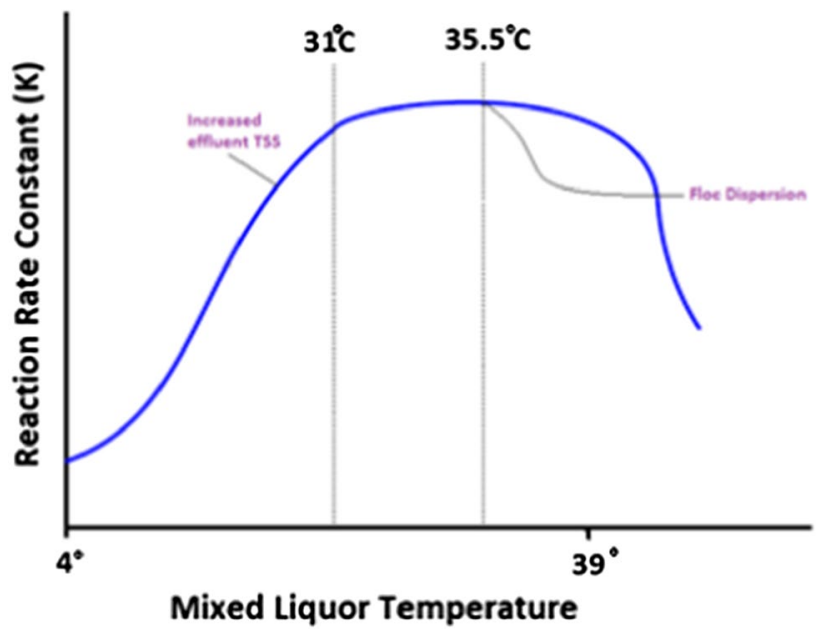

Fig. 3 Effect of temperature on biological treatment (aerobic)

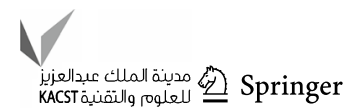


where $T=10-30{ }^{\circ} \mathrm{C}$ and $v$ is ranging between 0.113 and 0.0669 , respectively.

Moreover, increasing the temperature causes an increase in BOD removal efficiency, when the efficiency is about $40 \%$ at the temperature $10{ }^{\circ} \mathrm{C}$ and it becomes $70 \%$ at $30{ }^{\circ} \mathrm{C}$ (Von Sperling and de Lemos Chernicharo 2005). Furthermore, the removal rate of effluent COD was ranging $95-200 \mathrm{mg} / \mathrm{L}$ at temperature $30{ }^{\circ} \mathrm{C}, 110-210 \mathrm{mg} / \mathrm{L}$ at temperature $40{ }^{\circ} \mathrm{C}$ and $250-350 \mathrm{mg} / \mathrm{L}$ at temperature $50{ }^{\circ} \mathrm{C}$ during the biological treatment (Ab Halim et al. 2016), while the optimum temperature is $30{ }^{\circ} \mathrm{C}$ for biological activity granules (Zhiwei et al. 2009). Soluble COD removal efficiency declined as temperature increased from $30{ }^{\circ} \mathrm{C}(62 \%)$ to $60{ }^{\circ} \mathrm{C}(38 \%)$. The operation of aerobic biological wastewater treatment reactors at elevated temperatures can have adverse effects on process performance (LaPara et al. 2001).

\section{Anaerobic (anoxic) process}

It is the treatment which reduces the concentration for industrial sewage and wastewater of domestic under anoxic condition and higher temperatures more $30{ }^{\circ} \mathrm{C}$ and releasing biogas. It is occurring in the absence of oxygen, and increase in temperature caused increase in the levels of algae and others organic matters in raw matters (Viessman et al. 2009). During this process, the waste sludge is converted to $\mathrm{CH}_{4}$ and $\mathrm{CO}_{2}$; therefore, the design of digestion tank size depends on the reaction time which standardly depends on the temperature values; furthermore, the temperature ranges from 27 to $37^{\circ} \mathrm{C}$ and advised design temperature is about $33{ }^{\circ} \mathrm{C}$ (Pinar 2013). The temperature inside anaerobic digesters should be kept near $35^{\circ} \mathrm{C}$ for their good operational performance. This is especially true for cold climate regions, where raw sludge temperature may be lower than $15^{\circ} \mathrm{C}$ (Andreoli et al. 2007). The COD removal efficiency was more than $50 \%$ in summer and below $40 \%$ in winter with no evolution of biogas (Bandaraet al. 2012).

On another hand, methane-producing bacteria have particularly controlled the anaerobic process and it has higher sensitivity for changing of temperature. The methane-producing bacteria are considered more active in the temperature between 26 and $65^{\circ} \mathrm{C}$. For example, all the anaerobic digesters in the USA are within these ranges of temperature (Cheremisinoff 1997). Basically, moreover, volume of gas occupied by one mole of $\mathrm{CH}_{4}$ increases gradually with the temperature based on the law of universal gas, when the volume of one mole of $\mathrm{CH}_{4}$ is more than $25 \mathrm{~L}$ at the temperature $35{ }^{\circ} \mathrm{C}$. Besides that, in many cases, the optimal temperature for hydrogen sulfide was found between 35 and $50{ }^{\circ} \mathrm{C}$ (Yang and Allen 1994; Bajpai 2014).
Basically temperature of reaction rates at $30{ }^{\circ} \mathrm{C}$, are commonly considered significant for biological wastewater treatment. Sometimes, the values of methanogenesis will be decreased from 7.8 to 3.2 day when the temperature increases from 20 to $35^{\circ} \mathrm{C}$ because the methanogenic growth kinetic is truly important for anaerobic process (Lawrence and McCarty 1970; Metcalf and Eddy 2003; Safoniuk 2004). Through the lower temperature at $10-20{ }^{\circ} \mathrm{C}$, the anaerobic treatment usually is continued in the reactors of suspended and attached growth; moreover, the long-chain fatty acids degradation is limited during these ranges of temperature. However, the economics and feasibility of anaerobic treatment have been affected by change in the temperature.

The increase in temperature reduces the saturation concentration; clearly, the greater agitation of molecules in the water tends to make the dissolved gases pass to the gas phase (Von Sperling 2007). The percentage of carbon dioxide gas $\left(\mathrm{CO}_{2}\right)$ phase (alkalinity) often increases simulants ally with any increase in temperature. The acidity caused by hydrogen sulfide $\left(\mathrm{H}_{2} \mathrm{~S}\right)$ is increasing with the temperature, while ionized ammonia $\left(\mathrm{NH}_{4}{ }^{+}\right)$concentration decreases if the temperature goes up (Metcalf and Eddy 2003). Therefore, the activities of biological treatment reduce if the temperature is above $65^{\circ} \mathrm{C}$, so most of common pathogens and parasites will die within one hour at the temperatures between 55 and $65{ }^{\circ} \mathrm{C}$ (Tchobanoglous 1993), while the removal rates of ammonia were decreased with the temperature values which have been reported to be $84.34 \%$ at $30{ }^{\circ} \mathrm{C}, 71.13 \%$ at $40 \%$ and $9.31 \%$ at $50{ }^{\circ} \mathrm{C}$ (Tchobanoglous 1993).

\section{Biological nutrient removal (BNR)}

The process is used to remove total nitrogen or total phosphorus or both of them from wastewater by using the microorganisms under different environmental circumstances. Total nitrogen comprises ammonia, nitrite, particulate organic nitrogen and soluble organic nitrogen. The biological removal of nitrogen is done by two processes nitrification and denitrification. In the first process, ammonia oxidized into nitrite and then into nitrate. During denitrification process, nitrate nitrogen is deformed biologically to nitrogen gases in the absence of oxygen (denitrification) as shown in the flowing reaction (Metcalf and Eddy 2003; Spellman 2009):

$\mathrm{NH}_{3}+\mathrm{NO}_{3}^{-}=\underline{\text { Pseudomonas }} \mathrm{H}_{2} \mathrm{O}$ or $\mathrm{N}_{2}$.

During the denitrification process, bacteria work to reduce the nitrite or nitrate to nitrogen gases (Cheremisinoff 1997). At temperature $35^{\circ} \mathrm{C}$, the removal efficiency of nitrogen has been reported to about $80-85 \%$ in a bench-scale research during anoxic process to provide 
an electronic donor (Metcalf and Eddy 2003). A specific wastewater treatment is achieved simultaneously by group of aerobic, anaerobic and anoxic processes. When temperature is between 30 and $35{ }^{\circ} \mathrm{C}$, the novel autotrophic ammonia strength in anaerobic digestion increases in the liquidized base reactor. The liquidized bed reactor has impact on slowing of bacteria growth (Strous et al. 1997). Moreover, overthought chemoheterotrophic bacteria is able of slow growth in the dark or in dim light which be building carboniferous elements becomes fundamentally inanimate (Safoniuk 2004). On the other hand, the autotrophic-nitrifying bacteria especially will cease functioning at temperature $5{ }^{\circ} \mathrm{C}$.

The biological phosphorus removal occurs without nitrification, when the value of desirable SRT is about 2.5 days at temperature $20^{\circ} \mathrm{C}$ and it increases to 4.5 days when the temperature decreases to $10{ }^{\circ} \mathrm{C}$ (Nielsen et al. 1999). Moreover, an effluent phosphate concentration is gradually increased $8.3 \mathrm{mg} / \mathrm{L}$ at $30{ }^{\circ} \mathrm{C}, 14 \mathrm{mg} / \mathrm{L}$ at $40{ }^{\circ} \mathrm{C}$ and $17 \mathrm{mg} / \mathrm{L}$ at $50{ }^{\circ} \mathrm{C}$. Additionally, the phosphorous atomic number ratios were decreased from $0.72,0.1$ and $0.0187 \%$ for the matured granules at 30,40 and $50{ }^{\circ} \mathrm{C}$, respectively. Usually, the SVI values of biomass at different temperatures 30,40 and $50{ }^{\circ} \mathrm{C}$ were decreased from 63.21, 47.4 and $24.5 \mathrm{mg} / \mathrm{L}$, respectively (Ab Halim et al. 2016).

\section{Concluding remarks}

BTW has been widely applied to municipal/domestic wastewater treatment systems. BTW is basically the most important stage in wastewater treatment plant; during this process, $60 \%$ of the pollutants in sewage fluids is removed. Besides that, some factors have effects on biological wastewater treatment; therefore, the study of these factors is considered significantly more important for the enhancement and development of the wastewater treatment that varies across world. A major goal of this review was to study the enhancement effect of temperature on BTW. However, variable temperature has significant effects on process performance. Therefore, it is essentially to understand a performance of BTW in different temperatures; this leads to increase in the knowledge of best following ways related to removal efficiency. The recommendation of this research presented here may facilitate improvements in the understanding of the temperature impacts on biological treatment for wastewater in different regions.

Acknowledgements We gratefully acknowledge the financial support of the Ministry of Municipalities and Public Works, and the Ministry of Higher Education in Iraq. We are also grateful to Alkafeel Center for Studies, Researches and Engineering Consultations Alabass Holy Shrine organization in Karbala city, Iraq, Grant No. 2500.

Open Access This article is licensed under a Creative Commons Attribution 4.0 International License, which permits use, sharing, adaptation, distribution and reproduction in any medium or format, as long as you give appropriate credit to the original author(s) and the source, provide a link to the Creative Commons licence, and indicate if changes were made. The images or other third party material in this article are included in the article's Creative Commons licence, unless indicated otherwise in a credit line to the material. If material is not included in the article's Creative Commons licence and your intended use is not permitted by statutory regulation or exceeds the permitted use, you will need to obtain permission directly from the copyright holder. To view a copy of this licence, visit http://creativecommons.org/licenses/by/4.0/.

\section{References}

American Public Health Association, American Water Works Association, Water Pollution Control Federation, and Water Environment Federation (1915) Standard methods for the examination of water and wastewater, vol 2. American Public Health Association, Washington, DC

Andreoli CV, Von Sperling M, Fernandes F, Ronteltap M (2007) Sludge treatment and disposal. IWA Publishing, London

Ab Halim MH, Anuar AN, Jamal NSA, Azmi SI, Ujang Z, Bob MM (2016) Influence of high temperature on the performance of aerobic granular sludge in biological treatment of wastewater. J Environ Manag 184:271-280

Batstone DJ, Keller J, Angelidaki I, Kalyuzhnyi SV, Pavlostathis SG, Rozzi A, Vavilin VA (2002) The IWA anaerobic digestion model no 1 (ADM1). Water Sci Technol 45(10):65-73

Bandara WM, Kindaichi T, Satoh H, Sasakawa M, Nakahara Y, Takahashi M, Okabe S (2012) Anaerobic treatment of municipal wastewater at ambient temperature: analysis of archaeal community structure and recovery of dissolved methane. Water Res 46(17):5756-5764

Bajpai P (2014) Biological odour treatment. Springer, Berlin

Cheremisinoff NP (1997) Biotechnology for waste and wastewater treatment. Elsevier, Amsterdam

Eckenfelder WW (1980) Principles of water quality management. CBI Publishing Company Inc, Boston

El Saliby IJ, Shon H, Kandasamy J, Vigneswaran S (2008) Nanotechnology for wastewater treatment: in brief. Encycl Life Support Syst (EOLSS).

Eckenfelder WW, O'Connor DJ (2013) Biological waste treatment. Elsevier, Amsterdam

Grady CL, Kirsch EJ, Koczwara MK, Trgovcich B, Watt RD (1984) Molecular weight distributions in activated sludge effluents. Water Res 18(2):239-246

Hydromantis (2020) https://www.hydromantis.com/GPSX-innov ative.html

Jenkins D (1992) Towards a comprehensive model of activated sludge bulking and foaming. Water Sci Technol 25(6):215-230

Metcalf L, Eddy HP (2003) Wastewater engineering treatment and reuse. McGraw-Hill, New York

Metcalf L, Eddy HP (2004) Wastewater engineering, treatment and reuse. McGraw-Hill, New York

Nielsen AT, Liu WT, Filipe C, Grady L, Molin S, Stahl DA (1999) Identification of a novel group of bacteria in sludge from a deteriorated biological phosphorus removal reactor. Appl Environ Microbiol 65(3):1251-1258 
Lawrence AW, McCarty PL (1970) Unified basis for biological treatment design and operation. J Sanit Eng Div 96(3):757-778

LaPara TM, Nakatsu CH, Pantea LM, Alleman JE (2001) Aerobic biological treatment of a pharmaceutical wastewater: effect of temperature on COD removal and bacterial community development. Water Res 35(18):4417-4425

Obaid HA, Shahid S, Basim KN, Chelliapan S (2015) Modeling of wastewater quality in an urban area during festival and rainy days. Water Sci Technol 72(6):1029-1042

Popel HJ (1979) Aeration and gas transfer, 2nd edn. Delft University of Technology, Delft

Pinar WF (2013) International handbook of curriculum research. Routledge, London

Sawyer CN, McCarty PL, Parkin GF (1978) Chemistry for environmental engineers. Mc Graw-Hill, New York

Stul EW, Mc Ghee TJ (1982) Water supply and sewerage. McGrawHill, New York. https://www.abebooks.com/book-search/kw/ water-supply-and-sewerage-e-w-steel-terence-j-mcghee/

Strous M, Van Gerven E, Zheng P, Kuenen JG, Jetten MS (1997) Ammonium removal from concentrated waste streams with the anaerobic ammonium oxidation (anammox) process in different reactor configurations. Water Res 31(8):1955-1962

Spellman FR (2009) Water and wastewater treatment plant operations. New York 2003. 17 Iurciuc CE Teză de doctorat. Studii şi cercetări privind epurarea avansată a apelor uzate în vederea valorificării efluentului la irigarea culturilor energetice. Iași 2013

Safoniuk M (2004) Wastewater engineering: Treatment and reuse. Chem Eng 111(7):10-12
Von Sperling M (2007) Wastewater characteristics, treatment and disposal. IWA Publishing, London

Von Sperling M, de Lemos Chernicharo CA (2005) Biological wastewater treatment in warm climate regions, vol 1. IWA publishing

Tchobanoglous G (1993) Integrated solid waste management engineering principles and management issues. McGraw-Hill, New York

Tchobanoglous G, Metcalf AK, Eddy AC, Tchobanoglous G, Metcalf MEM, Metcalf JL, Eddy HP (1991) Wastewater engeneering: treatment, disposal and reuse

Viessman W, Hammer MJ, Perez EM, Chadik PA (2009) Water supply and pollution control. Prentice Hall, Upper saddle River

Yánez Cossio F (1993). Lagunas de estabilización: teoría, diseño, evaluación y mantenimiento. In: Lagunas de estabilización: teoría, diseño, evaluación y mantenimiento. IEOS

Yang Y, Allen ER (1994) Biofiltration control of hydrogen sulfide 1 Design and operational parameters. Air Waste 44(7):863-868

Zhiwei SONG, Nanqi REN, Zhang K, Longyan TONG (2009) Influence of temperature on the characteristics of aerobic granulation in sequencing batch airlift reactors. J Environ Sci 21(3):273-278

Publisher's Note Springer Nature remains neutral with regard to jurisdictional claims in published maps and institutional affiliations. 